Portland State University

PDXScholar

6-1-1976

\title{
A Descriptive Study of Eleven Parent Conferences in a Child Development Center
}

Yolanda A. Moser

Portland State University

Follow this and additional works at: https://pdxscholar.library.pdx.edu/open_access_etds

Part of the Social Work Commons

Let us know how access to this document benefits you.

\section{Recommended Citation}

Moser, Yolanda A., "A Descriptive Study of Eleven Parent Conferences in a Child Development Center" (1976). Dissertations and Theses. Paper 1777.

https://doi.org/10.15760/etd.1776

This Thesis is brought to you for free and open access. It has been accepted for inclusion in Dissertations and Theses by an authorized administrator of PDXScholar. Please contact us if we can make this document more accessible: pdxscholar@pdx.edu. 
AN ABSTRACT OF THE PRACTICUM OF Yolanda A. Moser for the Master of Social Work presented June 1, 1976.

Title: A Descriptive Study of Eleven Parent Conferences in a Child Development Center

APPROVED BY,

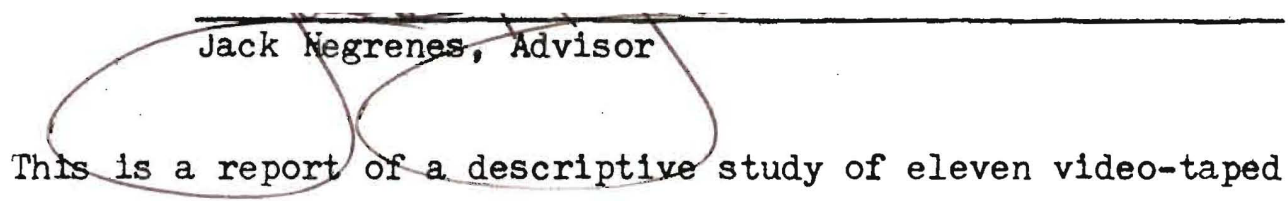
diagnostic conferences involving parents of developmentally delayed children who have been assessed at a training facility which provides diagnostic services to a variety of delayed or handicapped children. The variables described were: (1) the amount of verbal participation of staff and parents; and (2) parent ratings of satisfaction obtained from a brief questionnaire administered orally.

The data revealed that: (1) there is no relationship between parent verbal participation and parent satisfaction with the conference; and (2) there is a relationship between parent satisfaction and process and content factors in the parent conference. 


\section{A DESCRIPTIVE STUDY OF ELEVEN PARENT \\ CONFERENCES IN A CHILD \\ DEVELOPMENT CENTER}

by

YOLANDA A. MOSER

A practicum submitted in partial fulfillment of the requirements for the degree of

MASTER OF SOCIAL WORK

Portland State University

1976 
TO THE OFFICE OF GRADUATE STUDIES AND RESEARCH

The Advisor approves the practicum of Yolanda A. Maser presented June 1, 1976.

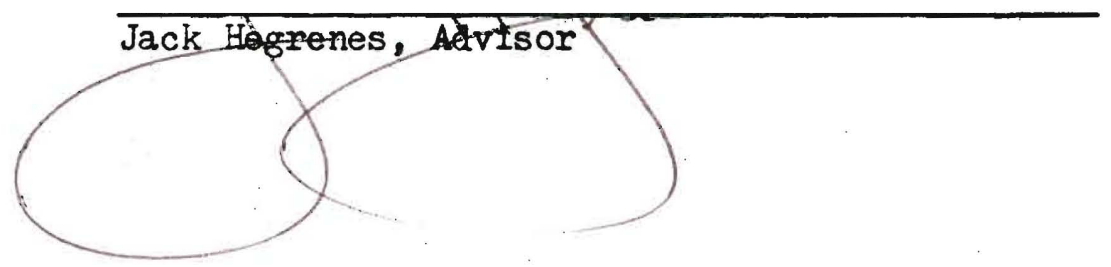




\section{ACKNOWLEDGMENTS}

The author of this report is greatly indebted to Dr. Jack Hegrenes, Associate Professor and Social Work Training Director of the Child Development and Rehabilitation Center, University of Oregon Medical School. It was he who suggested the inquiry into parent conferencing, and it was his support and advice that helped the author complete the study.

The author wishes to thank Dr. Russell Jackson, Associate Professor of Medical Psychology, at the Child Development and Rehabilitation Center, for his helpful suggestions and welcome encouragement throughout the study.

Special appreciation is due Mr. Stanley Hansen, Director of Instructional Technology, Crippled Children's Division, for his patience and helpfulness during the taping of the conferences. Finally, the author is grateful to the parents and the staff at the Child Development and Rehabilitation Center who contributed to the study by allowing themselves to be video-taped during their parent conferences. 
TABLE OF CONTENTS

PAGE

ACKNOWLEDGMENTS . . . . . . . . . . . . . . . LIST OF TABLAS

LIST OF FIGURES . . . . . . . . . . . . . . . . . .

vi

CHAPTER

I INTRODUCTION ..................

II METHOD OF INQUIRY . . . . . . . . . . 3

Procedure for Obtaining the Data. . . . . . 3

III DESCRIPTION OF THE STUDY IN DETAIL. . . . . . . ? ?

The Patients. . . . . . . . . . ?

The Families. . . . . . . . . 10

The Conferences ......... 12

Verbal Participation. .......... 14

IV PARENTS' SATISFACTION WITH THE CONFERENCES. . . . 30

The Questionnaire........ 30

Discussion .............. 35

V CONCLUSIONS .......................... 42

SOURCES CONSULTED . . . . . . . . . . . . . . . . 43

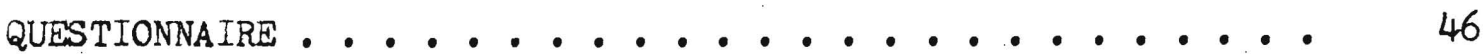


I. MAJOR DIAGNOSES IN THE CHILD DEVELOPMENT CLINIC . . . . 4

II. PARENT CONFERENCE PARTICIPANTS AND DIAGNOSES . . . . 8

III. FAMILY COMPOSITION (WITH AGES) . . . . . . . . 11

IV. DISCIPLINES IN THE PARENT CONFERENCES . . . . . . . 13

V. VERBAL PARTICIPATION OF STAFF AND PARENTS . . . . . 15

VI. RANKED VERBAL PARTICIPATION RATES . . . . . . 16

VII. SILENCE IN THE PARENT CONFERENCES . . . . . . . . 17

VIII. PARENT SATISFACTION . . . . . . . . . . . 32

IX. WHAT PARENTS LIKED AND DISLIKED ABOUT THE CONFERENGES • • 33

X. CLASSIFICATION OF RESPONSES . . . . . . . . 36

XI. FISHER'S EXACT . . . . . . . . . . 37

XII. PARENT RESPONSES TO QUESTION \#4 . . . . . . . . 38

XIII. PARENT RESPONSES TO QUESTION \#5 ............... 39 


\section{LIST OF FIGURES}

FIGURE PAGE

1. VERBAL PARTICIPATION, TAPE \#1 . . . . . . . 19

2. VERBAL PARTICIPATION, TAPE \#2 . . . . . . . 20

3. VERBAL PARTICIPATION, TAPE \#3 . . . . . . . . 21

4. VERBAL PARTICIPATION, TAPE \#4 . . . . . . . 22

5. Verbal PARTICIPATION, TAPE \#5.......... 23

6. Verbal PARTICIPATION, TAPE \#6 ........... 24

7. VERBAL PARTICIPATION, TAPE \#? . . . . . . . 25

8. VERBAL PARTICIPATION, TAPE \#8 . . . . . . . . 26

9. VERBAL PARTICIPATION, TAPE \#9 .......... 27

10. VERBAL PARTICIPATION, TAPE \#10........... 28

11. VERBAL PARTICIPATION, TAPE \#11. . . . . . . . 29 


\section{CHAPTER I}

\section{INTRODUCTION}

The diagnostic conference is regarded by some as the most important product associated with the diagnostic services rendered by a child study clinic. It is, in fact, the vital link between the findings and recommendations made by the team of professionals examining a child and the actual implementation of those ideas in the form of management.

The parent conference is commonly associated with patient education; therefore, it might be viewed simply as a learning experience. The Iiterature, however, consistently suggests that there are several more functions at least as, if not more important than, patient education. Harriet L. Rheingold (1945), giving specific guidelines for interpreting diagnostic findings to parents, advises that parents first need to be reassured of staff's empathy and understanding. The child's future is discussed in accordance with the parent's receptivity, and cause is addressed to reduce feelings of guilt. Feelings are talked about. Finally, plans for action are made.

The Child Development Clinic of the Child Development and Rehabilitation Center, University of Oregon Medical School, generally subscribes to Rheingold's philosophy. The video-taping from which the data for this study was taken, was initiated by training directors seeking to enrich the training of those students who participate in parent conferencing at the Center. 
This study describes the amount of verbal participation of staif and parents in eleven parent conferences. In addition, parent satisfaction with these conferences is measured by the use of a short questionnaire. The analys is of the data is followed by a discussion of the application of the findings to the assessment of parent conference effectiveness. 
CHAPTER II

METHOD OF INQUIRY

Procedure for Obtaining the Data The first step in gathering the data consisted of video-taping eleven parent conferences so that staff and parent speaking times could be measured with accuracy at a later time. There was a total of nineteen parent conferences in the Child Development Clinic of the Child Development and Rehabilitation Center, ten of which were taped. An eleventh tape was taken from a similar clinic in the Child Development Program. Table I lists the major diagnoses, age and sex of the patient population during the October, 1975, to March, 1976, data-gathering period. Reasons for not taping certain conferences included such problems as reticence on the part of parents, conferencing in a foreign language, and various technical difficulties.

Every parent signed the release for taping with the understanding that the tapes would be used for training and research purposes. Parents were advised that their tape would be available for them to view.

In many instances the first two minutes of the parent conferences were not taped, and in several cases, the last fifteen to thirty minutes were untaped due to technical problems. 
TABLE I

MAJOR DIAGNOSES IN THE CHILD DEVELOPMENT CLINIC

AGE/SEXX

$10 \mathrm{yrs} \cdot \mathrm{F}$

$3 \mathrm{yrs} . / \mathrm{M}$

$4 \mathrm{yrs} . / \mathrm{F}$

$12 \mathrm{yrs} \cdot / \mathrm{M}$

$15 \mathrm{yrs} \cdot / \mathrm{M}$

$12 \mathrm{yrs} \cdot / \mathrm{F}$

$2 \mathrm{yrs} \cdot / \mathrm{M}$

$6 \mathrm{yrs} \cdot / \mathrm{M}$

$2 \mathrm{yrs} \cdot / \mathrm{M}$

$4 \mathrm{yrs} . / F$

$10 \mathrm{yrs} \cdot / \mathrm{M}$

$9 \mathrm{yrs} \cdot / \mathrm{M}$

$4 \mathrm{yrs} \cdot / \mathrm{s}$ inild retardation

mild muscle weakness

taped

ideopathic hypercalcemia

developmental delay

developmental delay

serous otitis

behavior problems

mental retardation with

hyperactivity, etiology

unknown

mental retardation

vocational needs

severe mental retardation

behavior problems

speech and language delay

chronic lung disease

heart disease

developmental delay

moderate developmental delay

marked gross motor delay

osteogenesis imperfecta

social, emotional

deprivation

social, emotional

deprivation

Down's syndrome

emotional disturbance

with autistic features

delayed speech and language

developmental delay secondary

to Seckle's syndrome taped

taped

taped

taped

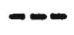

$-\infty$

.

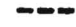

taped

$--$

$-$

$--$

taped 
TABLE I, continued

$1 \frac{1}{2} \mathrm{yrs} \cdot / \mathrm{F}$

$11 \mathrm{yrs} \cdot / \mathrm{F}$

$8 \mathrm{yrs} \cdot / \mathrm{M}$

$3 \mathrm{yrs} \cdot / \mathrm{F}$.

$11 \mathrm{yrs} \cdot / \mathrm{F}$

$20 \mathrm{yrs} \cdot / \mathrm{F}$

$6 \mathrm{yrs} \cdot / \mathrm{M}^{*}$ developmental delay

hearing loss

seizures

Down's syndrome

minimal brain dysfunction

developmental delay

hearing luss

paraplegia

myelomeningocele

mental retardation/deferred

Prater-Willi syndrome behavior/social problems

developmental delay

Down's syndrome

moderate mental retandation

behavioral problems taped

taped

taped

taped

taped

*case from Mini-clinic 
In order to measure the speaking times for staff (as a group) and for parents (as a group), the author played the tapes on the playback monitor while using an event recorder. Earphones were used to improve the sound so that the author could be more accurate in judging who was speaking when.

One key on the event recorder was depressed whenever staff spoke and another whenever parents spoke. In two instances the patients themselves participated in the conference. The keys were depressed during one-second pauses in speech. Both keys were depressed during similtaneous conversations. Laughter was recorded as speech. In April, 1976, from one to five months after the parent conference, each of the mothers was contacted and asked to respond to five questions regarding her satisfaction with the conference. The questionnaire was presented by telephone except in the case of one in-person contact and by letter in one instance when the family did not have a telephone. 


\section{CHAPTER III}

\section{DESCRIPTION OF THE STUDY IN DETAIL}

The Patients The eleven children evaluated in the Child Development Clinic, whose parent conferences were taped, ranged in age from one and one-half to twenty years, with eight years being the average age. There were five girls and six boys in the group. With the exception of two children (tapes \#1, \#4), all diagnoses included either developmental delay ( 5 cases) or mental retardation ( 4 cases). Although two different terms are used, what is significant is the fact that some degree of mental deficiency is present in all but two instances (see Table II).

Whereas most of the literature reviewed addressed the problems of initial diagnostic conferences, these children's parents had experienced many clinics prior to the evaluation at CDRC. A search of the medical records on file at the clinic indicated that just one couple had no experience in working with clinics (\#2). Although \#6 had not attended any specific clinic, this couple was experienced foster parents who had dealt with various health or service agencies for years. One couple (\#4) had had considerable involvement with the University of Oregon Medical School, and the remainder of the parents had worked with the Crippled Children's Division in Portland or Eugene. 
PARENT CONFERENCE PARTICIPANTS AND DIAGNOSES

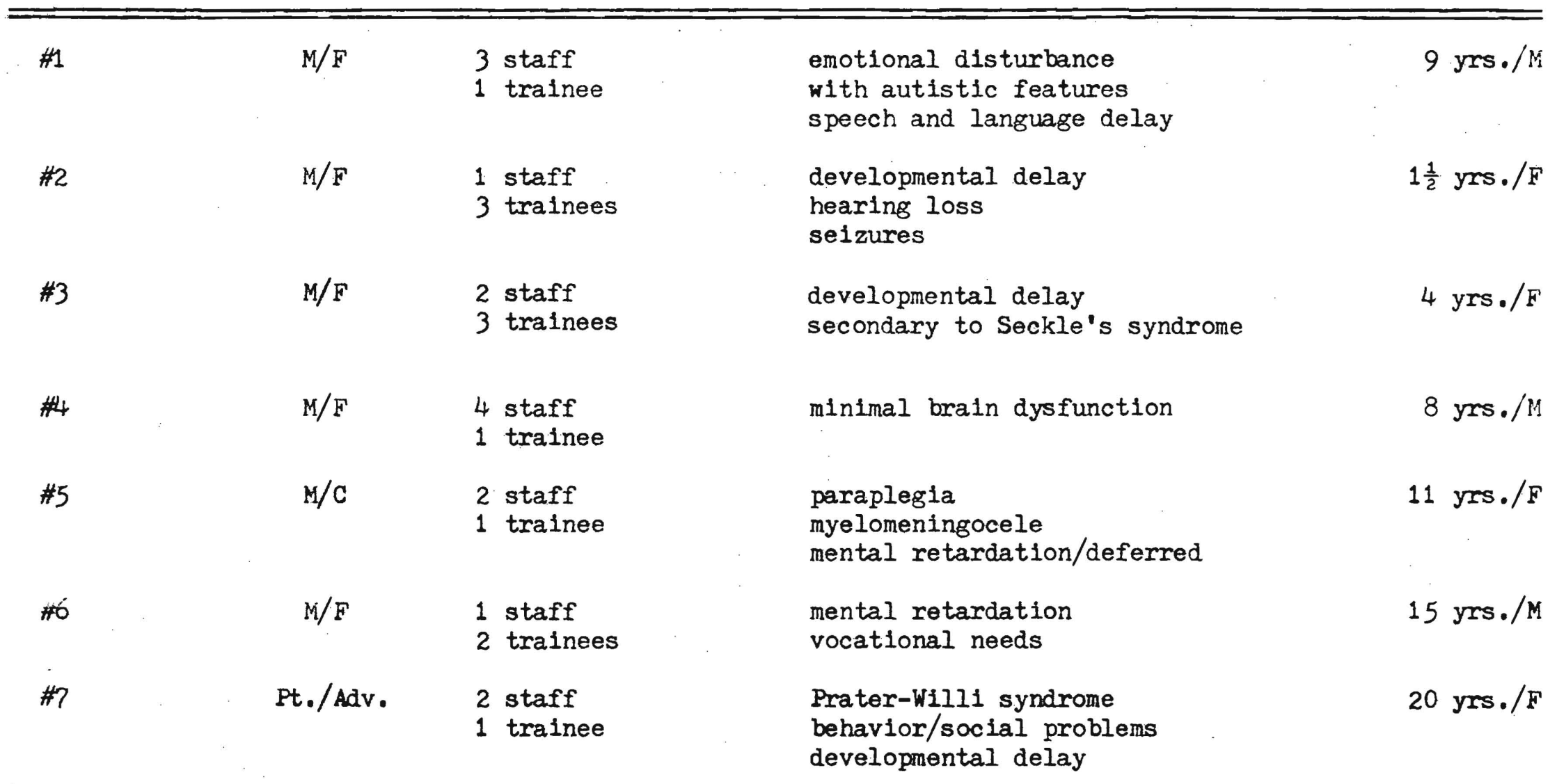




\section{TAPE \#}

$\begin{array}{lll}\text { \#8 } & M & 2 \text { staff } \\ & 1 \text { trainee } \\ \text { \#9 } & M / F & 1 \text { staff } \\ & 4 \text { trainees } \\ \text { \#10 } & 1 \text { staff } \\ & 5 \text { trainees } \\ & & 2 \text { staff } \\ & 3 \text { trainees }\end{array}$

Down's syndrome

moderate mental retardation

behavioral problems

ideopathic hypercalcemia

developmental delay

mild mental retardation

mild muscle weakness

chronic lung disease

heart disease

developmental delay
AGE/SEX

$6 \mathrm{yrs} . / \mathrm{M}$

3 yrs. $/ \mathrm{M}$

$10 \mathrm{yrs} . / \mathrm{F}$

2 yrs./M

* $M / C=$ mother/child

Pt./Adv. = patient/advocate 
The Families None of the patients are only children and none come from single-parent families. Case \#6 involves an adolescent who has been raised for several years by foster parents who have obtained guardianship on the boy. Case \#8 represents a foster child who has been in this placement most of his life. The parents range in age from 21 to 49 with the average father's age being 34 , and the average mother's age 32 years. Family composition is shown in Table III. 
TABLE III

FAMILY COMPOSITION (WITH AGES)

\begin{tabular}{|c|c|c|c|}
\hline TAPE \# & $\begin{array}{l}\text { PATIENT'S } \\
\text { AGE }\end{array}$ & $\begin{array}{l}\text { SIBLINGS } \\
\text { BY AGE }\end{array}$ & $\begin{array}{l}\text { PARENTS } \\
\text { BY AGE }\end{array}$ \\
\hline$\# 1$ & 9 & 15,11 & $\begin{array}{c}F / M \\
34 / 44\end{array}$ \\
\hline$\# 2$ & $1 \frac{1}{2}$ & 6 mos. & $23 / 21$ \\
\hline \#3 & 4 & 1 & $29 / 24$ \\
\hline$\# 4$ & 8 & 5, unborn & $30 / 26$ \\
\hline$\# 5$ & 11 & $20,19,17,8$ & $44 / 40$ \\
\hline \#6 & 15 & $18,16,13$ & $49 / 41 *$ \\
\hline$\# 7$ & 20 & $-\infty$ & -- \\
\hline$\# 8$ & 6 & $16,14,12$ & $43 / 40 * *$ \\
\hline$\# 9$ & 3 & 5 & $28 / 27$ \\
\hline \#10 & 10 & 4,6 & $34 / 27$ \\
\hline$\# 11$ & 2 & 13,9 & $32 / 30$ \\
\hline
\end{tabular}

* Iegal guardians

* foster parents 
The Conferences In the Child Development Clinic the parent conference is usually scheduled for the morning following the one-day evaluation of the child. In the one tape from the mini-clinic, the conference was held the afternoon following the morning of examinations and evaluations. Parent conferences in the full-day clinic are prepared for in the one and one-half hour staff meeting held at the end of the clinic day. In this meeting the staff and trainees of the various disciplines who have examined the child present their findings from which a problem list is made, along with treatment plans. Time is spent discussing any followup contacts that may need to be scheduled. A fifteen minute pre-conference staff meeting for those who will actually be in the parent conference is held just before the conference. Table IV lists the number of staff and trainee participants in the conferences. Disciplines participated according to the need for a particular expertise. Case coordinators, trainees assigned to gather initial information on the child and guide the family through the clinic, always participated in the conference. As can be seen in Table IV, medicine represents high staff and trainee participation, and disciplines such as psychology, social work, education and physical therapy show fewer participants in the taped conferences. 
TABLE IV

DISCIPLINES IN THE PARENT CONFERENCES

\begin{tabular}{|c|c|c|c|c|c|c|c|c|c|c|}
\hline 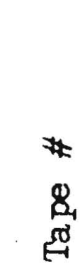 & 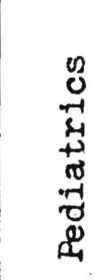 & 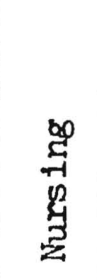 & 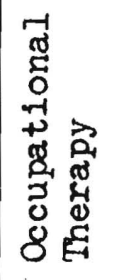 & $\begin{array}{l}\text { ¿ } \\
\Phi \\
\Phi \\
\Phi \\
\text { on }\end{array}$ & 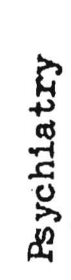 & 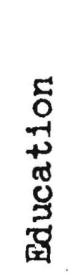 & 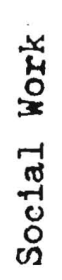 & 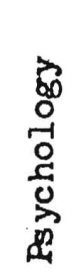 & 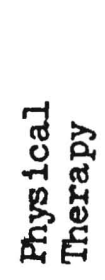 & 冨 \\
\hline 1 & & & $\mathrm{~T}$ & & $S$ & $S$ & $S$ & & & 4 \\
\hline 2 & $\mathrm{~S} / \mathrm{T}$ & & $\mathrm{T}$ & & & & & & $\mathrm{T}$ & 4 \\
\hline 3 & $s$ & $\mathrm{~S} / \mathrm{T}$ & $\mathrm{T}$ & & & & $\mathrm{T}$ & & & 5 \\
\hline 4 & $S$ & $S / T$ & & & & $S$ & & $S$ & & 5 \\
\hline 5 & & & & $T$ & $S$ & $S$ & & & & 3 \\
\hline 6 & & & $\mathrm{~T}$ & $\mathrm{~T}$ & & & $\mathrm{~T}$ & $S$ & & 4 \\
\hline 7 & $\mathrm{~S} / \mathrm{T}$ & & & & $S$ & & & & & 3 \\
\hline 8 & $S / T$ & & & & & & & $S$ & & 3 \\
\hline 9 & $\mathrm{~S} / \mathrm{T}$ & $T$ & & $\mathrm{~T}$ & $\mathrm{~T}$ & & & & & 5 \\
\hline 10 & $\mathrm{~S} / \mathrm{T}$ & $\mathrm{T}$ & $\mathrm{T}$ & $T$ & & & & & & 6 \\
\hline 11 & $\mathrm{~S} / \mathrm{T}$ & $\mathrm{T}$ & $\mathrm{S}$ & T & & & & & & 5 \\
\hline & 15 & $?$ & 6 & 5 & 4 & 3 & 3 & 3 & 1 & \\
\hline
\end{tabular}


Verbal Participation The eleven taped conferences ranged from thirtyfive to one hundred minutes in length (this is length of video-tapes. For estimated actual length, see Flgures 1 through 11). On the average, staff spoke twice as much of the time as did parents (see Table V). This table also shows the total speaking times for staff and parents for each conference. Table VI ranks the verbal participation rates from high to low for staff and parents.

As shown in Table VII, there was little silence in the parent conferences. Tapes \#5 and \#7 with $14 \%$ and $13 \%$ silence respectively, reflect the fact that these conferences were attended by patients with limited cognitive abilities (see Table II for diagnoses). Zero recorded silence can be attributed to the fact that more than one conversation took place at the same time. One key on the event recorder was depressed, even if two staff spoke simultaneously. The same held true for parents.

Figures 1 through 11 show staff and parent verbal participation rates plotted at five-minute intervals. In all but one conference, tape \#8, staff began the conference by speaking three out of the first five minutes.

The participation rate graphs might be interpreted as indicating reciprocity or lack of $1 t$. By this, the author means a more or less equal verbal exchange between staff and parents. The total speaking times are not the only indicators of parent participation. Regular, sawtooth patterns running near the center of the graph, as exemplified by $\# 8$, tend to reflect the fact that questions are being asked and responded to, and that those responses are eliciting requests for 
TABLE V

VERBAL PARTICIPATION OF STAFF AND PARENTS*

\begin{tabular}{|c|c|c|c|c|c|}
\hline TAFE \# & $\begin{array}{l}\text { IENGTH OF } \\
\text { CONFERENCE** } \\
\text { (taped) }\end{array}$ & $\begin{array}{l}\text { STA } \\
\text { (with }\end{array}$ & $\begin{array}{l}\text { FF SPEAKING } \\
\text { TIME } \\
\text { percentages) }\end{array}$ & $\begin{array}{l}\text { PAREN } \\
\text { (with pe }\end{array}$ & $\begin{array}{l}\text { PEAKING } \\
\text { entages) }\end{array}$ \\
\hline 1 & $59^{\circ}$ & $38^{\prime}$ & $64 \%$ & $20^{\prime}$ & $34 \%$ \\
\hline 2 & $62^{\circ}$ & $41^{\prime}$ & $66 \%$ & $17^{\circ}$ & $27 \%$ \\
\hline 3 & $100^{\circ}$ & $59^{\circ}$ & $59 \%$ & $444^{\prime}$ & $44 \%$ \\
\hline 4 & $96 !$ & $60^{\circ}$ & $62 \%$ & $34^{\circ}$ & $35 \%$ \\
\hline 5 & $65^{\circ}$ & $28^{\prime}$ & $43 \%$ & $28^{\prime}$ & $43 \%$ \\
\hline 6 & $52^{\prime}$ & $31^{\circ}$ & $60 \%$ & $22^{\circ}$ & $42 \%$ \\
\hline 7 & $58^{\prime}$ & $34^{\circ}$ & $59 \%$ & $16^{\prime}$ & $28 \%$ \\
\hline 8 & $35^{\prime}$ & $18^{\circ}$ & $51 \%$ & $16^{\prime}$ & $46 \%$ \\
\hline 9 & $62^{\prime}$ & $49^{\circ}$ & $79 \%$ & $11^{\circ}$ & $18 \%$ \\
\hline 10 & $35^{\circ}$ & $27^{\circ}$ & $77 \%$ & $7^{\circ}$ & $20 \%$ \\
\hline 11 & $61^{\circ}$ & $49^{\circ}$ & $80 \%$ & $9^{\prime}$ & $15 \%$ \\
\hline AVERAG & $62^{\circ}$ & $40^{\prime}$ & $64 \%$ & $20^{\circ}$ & $32 \%$ \\
\hline
\end{tabular}

* all times rounded to a full minute

** see estimated length of conferences in Figures 1-11 
TABLE VI

RANKED VERBAI PARTICIPATION RATES

TAPE \# ذTAFF

(in percentages)

TAPE \#

PARENTS*

(in percentages)

\begin{tabular}{|c|c|c|c|}
\hline 11 & $80 \%$ & 8 & $46 \%$ \\
\hline 9 & $79 \%$ & 3 & $44 \%$ \\
\hline \multirow[t]{2}{*}{10} & $77 \%$ & 5 & $43 \%$ \\
\hline & & 6 & $42 \%$ \\
\hline 2 & $66 \%$ & 4 & $35 \%$ \\
\hline 1 & $64 \%$ & 1 & $34 \%$ \\
\hline 6 & $60 \%$ & 7 & $28 \%$ \\
\hline 4 & $60 \%$ & 2 & $27 \%$ \\
\hline 7 & $59 \%$ & & \\
\hline 3 & $59 \%$ & & \\
\hline 8 & $51 \%$ & 10 & $20 \%$ \\
\hline 5 & $43 \%$ & 9 & $18 \%$ \\
\hline & & 11 & $15 \%$ \\
\hline
\end{tabular}

* Tape \#5 had mother-child participants and tape \#7 had patient-advocate participants. 
TABLE VII

SILENCE IN THE PARENT CONFERENCES

\begin{tabular}{ccc} 
TAPE \# & $\begin{array}{c}\text { S ILENCE } \\
\text { (in percentages) }\end{array}$ & $\begin{array}{c}\text { TOTAL SPEAKING } \\
\text { TIME } \\
\text { (in percentages) }\end{array}$ \\
\hline 1 & $2 \%$ & $98 \%$ \\
2 & $7 \%$ & $93 \%$ \\
3 & $0 \%$ & $103 \% *$ \\
4 & $3 \%$ & $97 \%$ \\
5 & $14 \%$ & $86 \%$ \\
6 & $0 \%$ & $102 \% *$ \\
7 & $13 \%$ & $87 \%$ \\
8 & $3 \%$ & $97 \%$ \\
9 & $3 \%$ & $97 \%$ \\
10 & $3 \%$ & $97 \%$ \\
11 & $5 \%$ & $95 \%$ \\
\hline
\end{tabular}

* Indicates more than one conversation at the same time or interruptions. 
further clarification. Parent conferences usually include the presentation of several reports with an opportunity for parents to respond after each report is given. Toward the end of the conference, when very specific information is given, such as names of referral agencles, or dates for return clinic appointments, parents would have additional time for comments and questions. In all but three conferences, tapes \#4, \#5, and \#9, ending participation rates are higher than beginning rates.

Chapter IV, in its analysis of a short questionnaire presented to the mothers, greatly enlarges upon and places in a more relevant position the verbal participation rates. 
Figure 1. Verbal participation, Tape \#1.

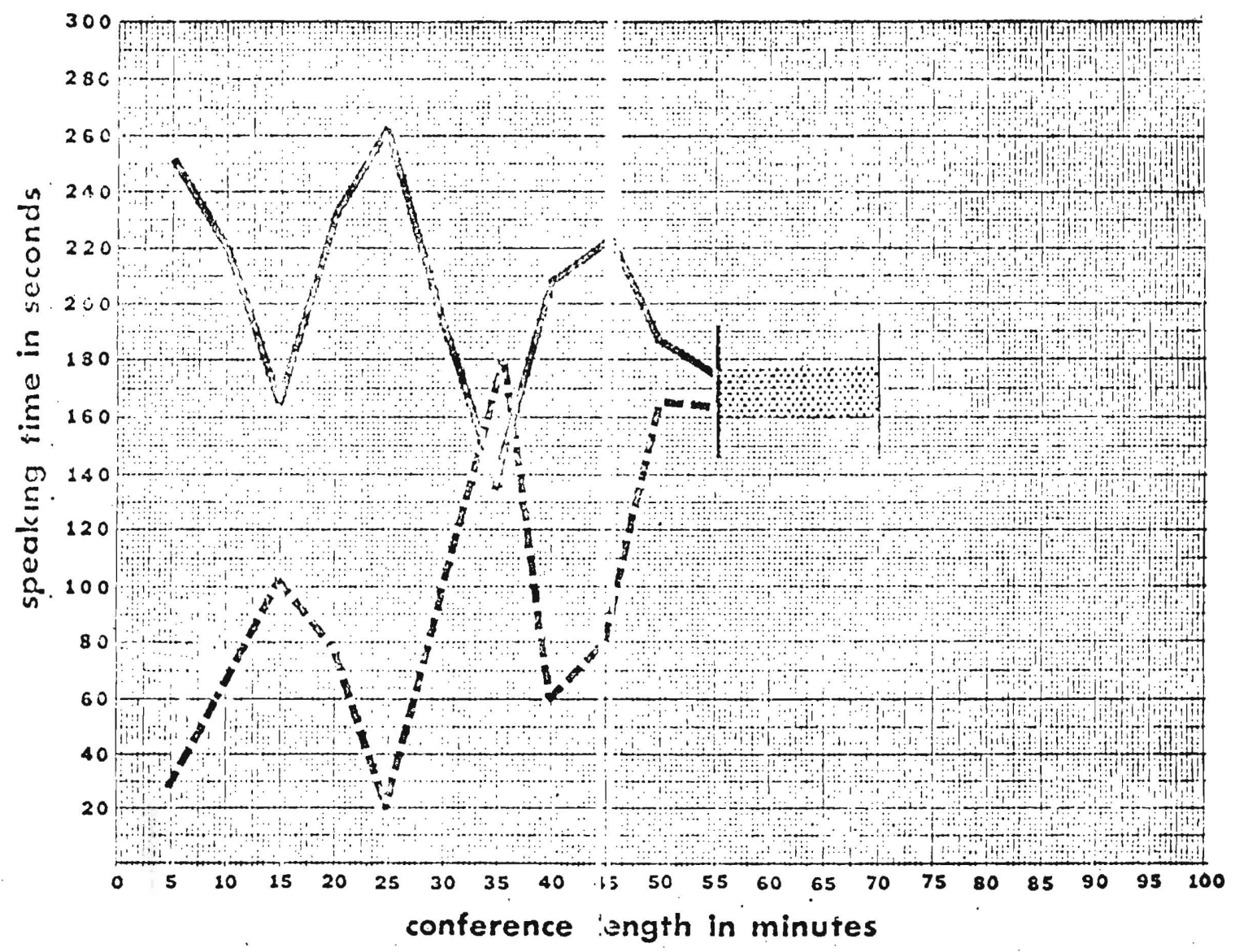

stoff speaking time

parent speaking time $=-m$

untaped segments? 
Figure 2. Verbal participation, Tape \#2.

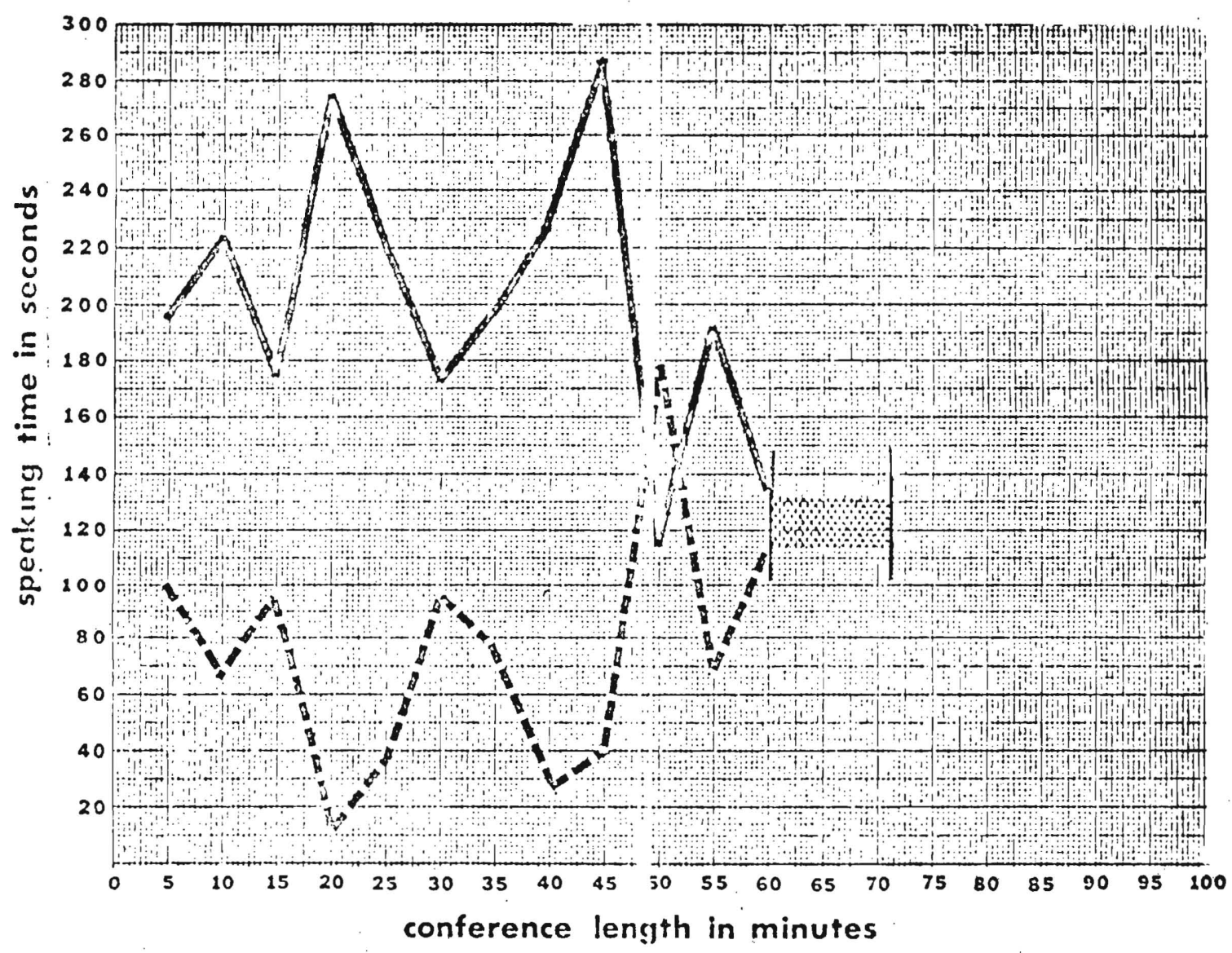

staff speaking time

- parent sceaking time

untaped

segments 
Figure 3. Verbal participation, Tape \#3.

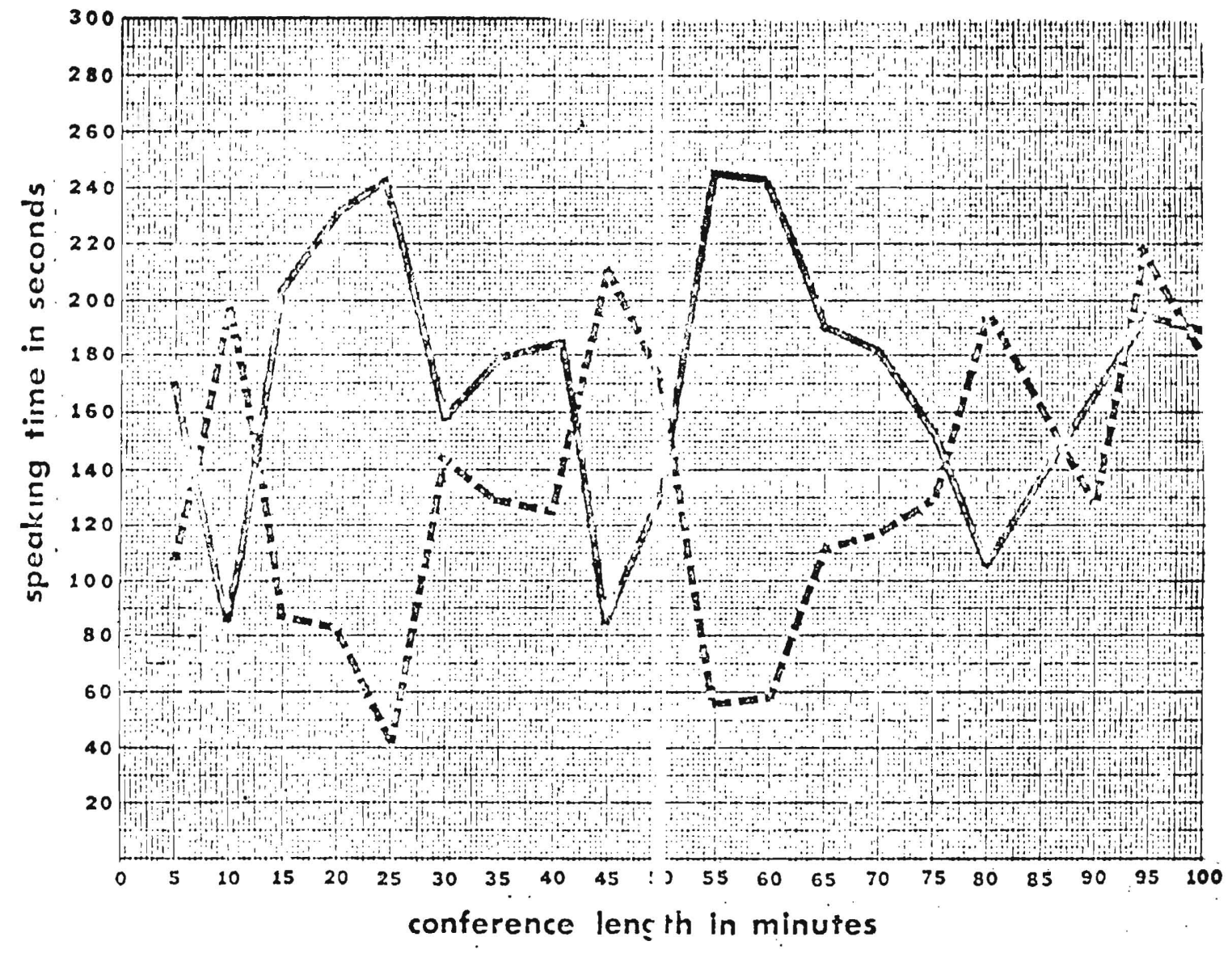

staff speaking tıme parent spilaking time $=-\begin{aligned} & \text { untaped } \\ & \text { segments }\end{aligned}$ 
Figure 4. Verbal participation, Tape \#4.

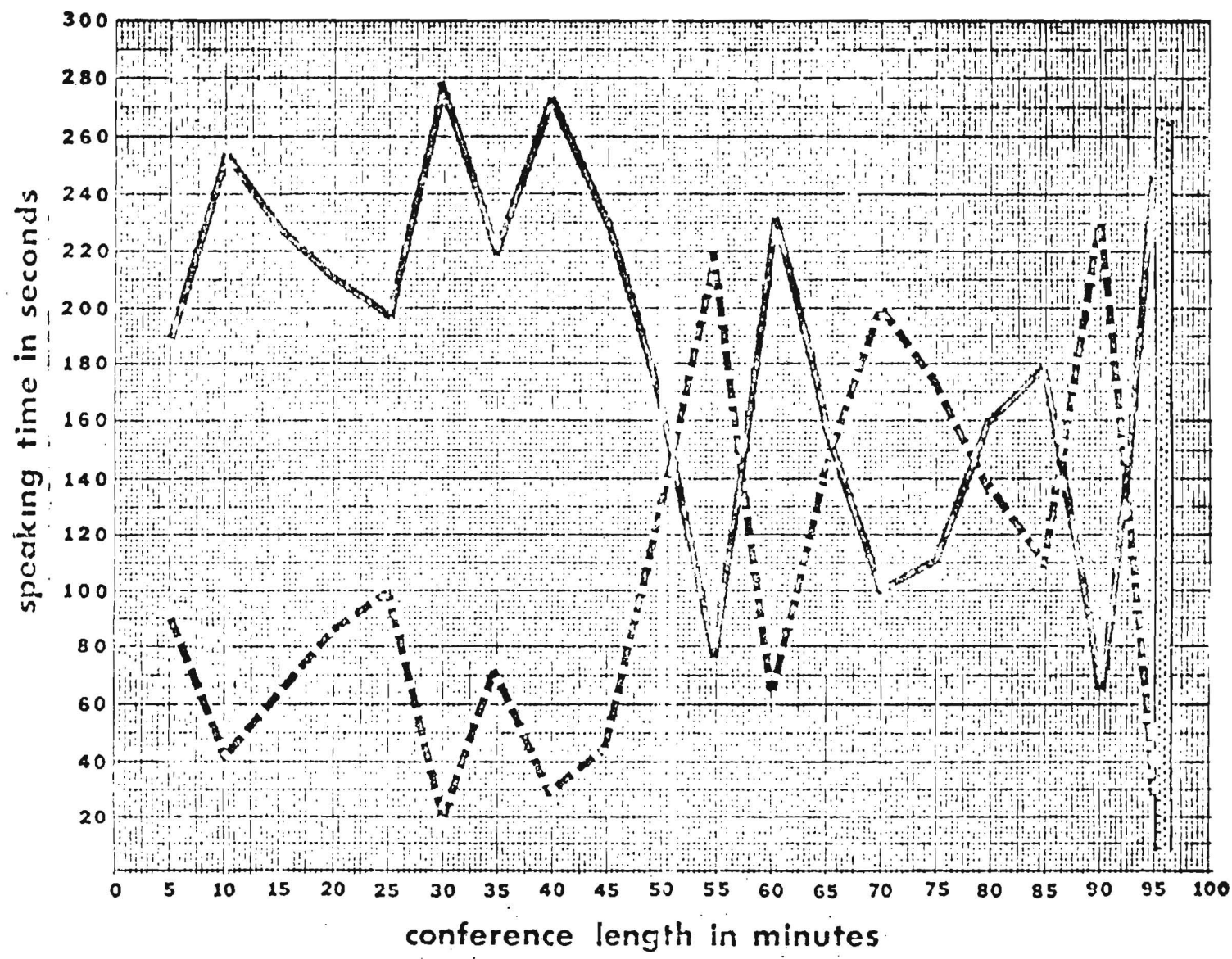

staff speaking time

untaped segments 
Figure 5. Verbal participation, Tape \#5.

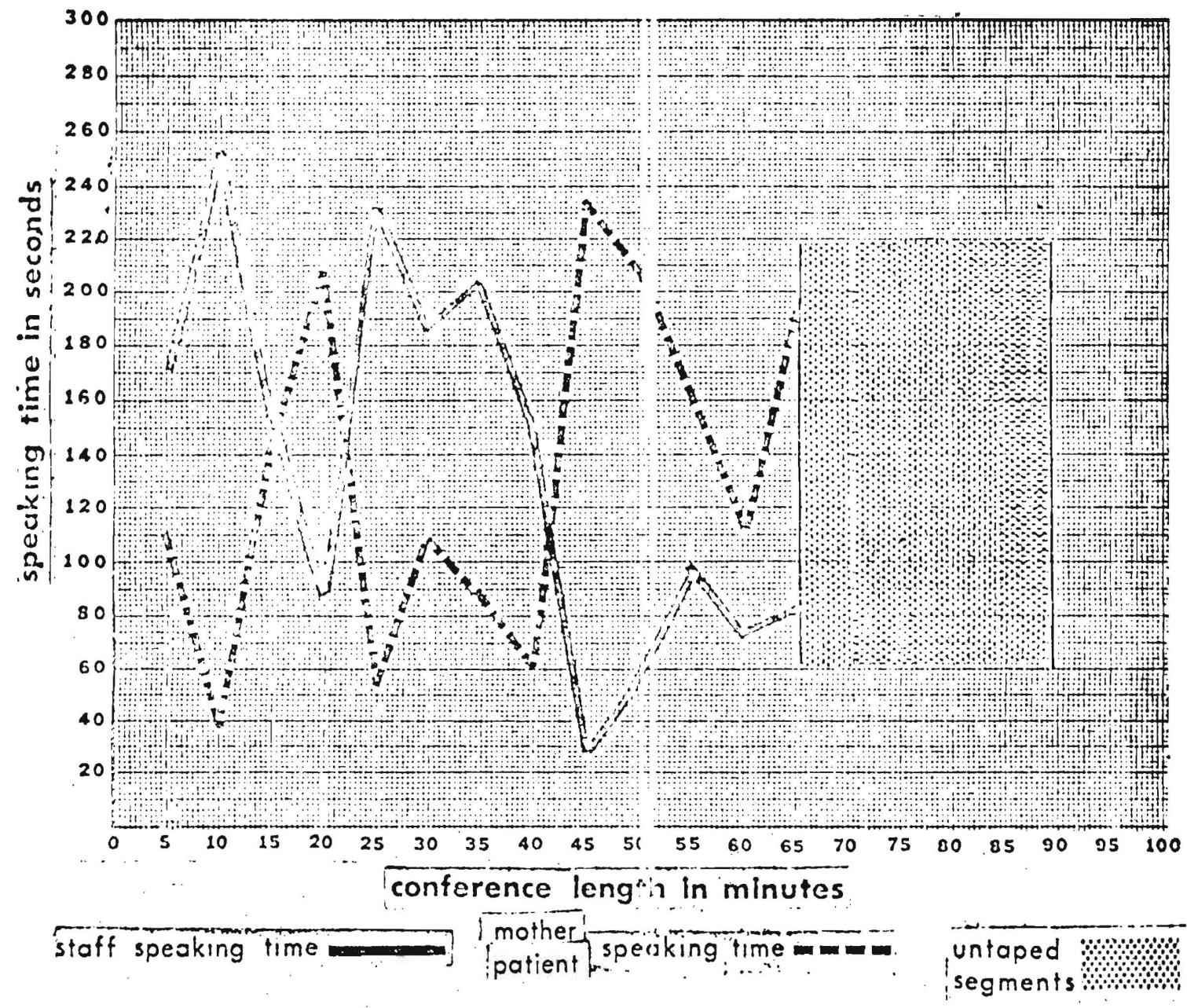


Figure 6. Verbal participation, Tape \#6.

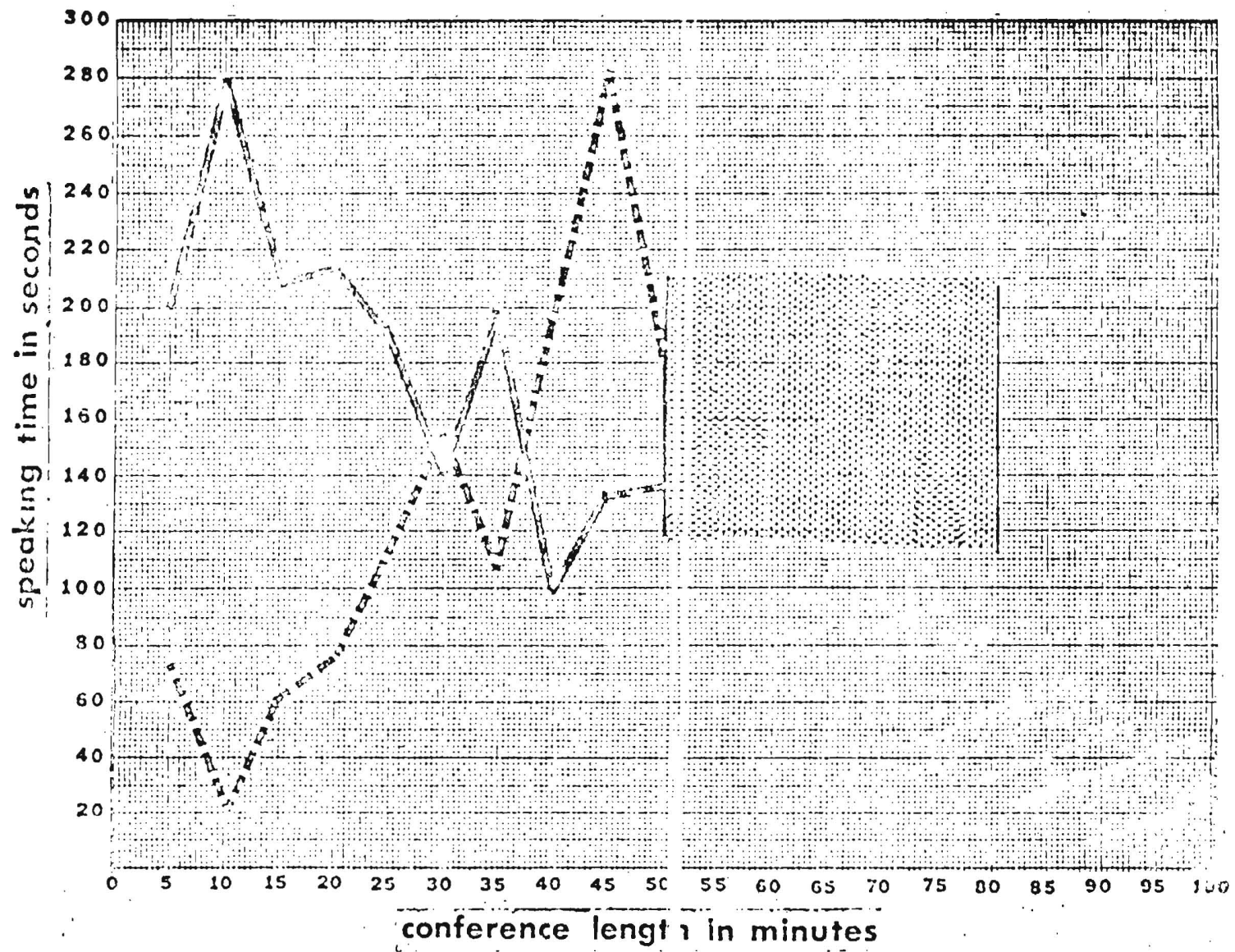

staff speaking time parent speciking time $=$ 
Figure 7. Verbal participation, Tape \#7.

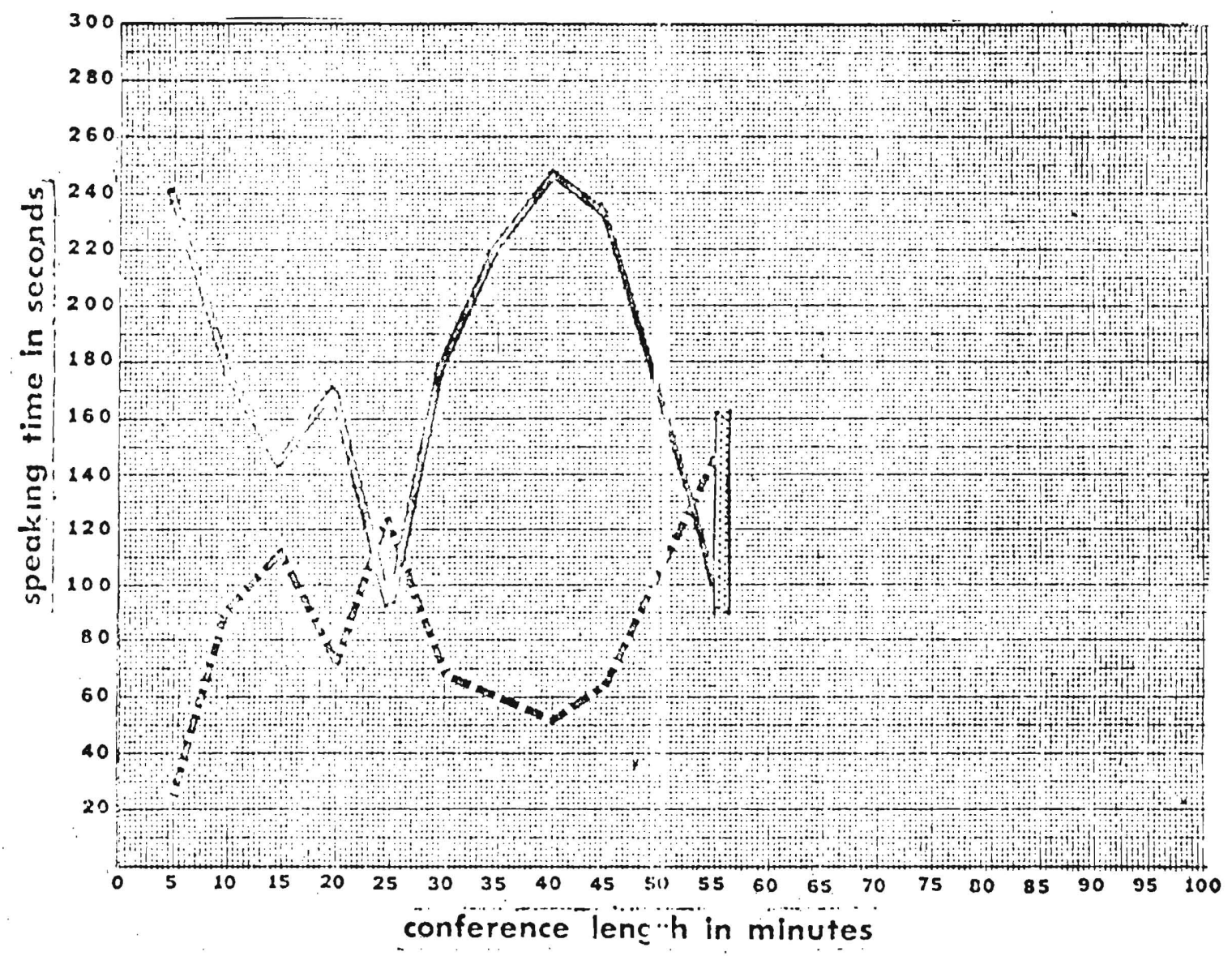

staft sperking time

patient advocate spraking time $=-m$ untaped segments 
Figure 8. Verbal participation, Tape \#8.

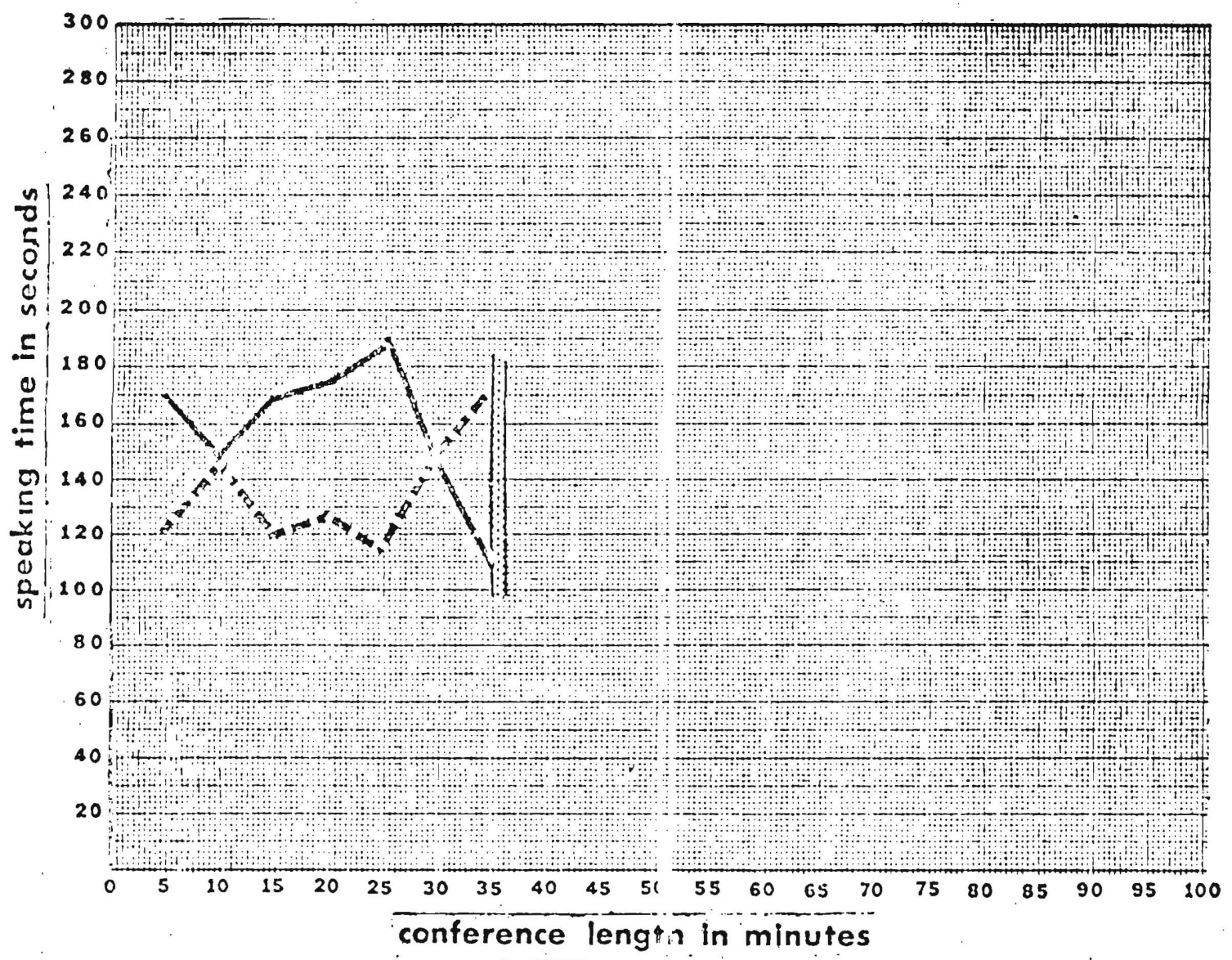

staff speaking time - foster speciking time-m=- 
Figure 9. Verbal participation, Tape \#9.

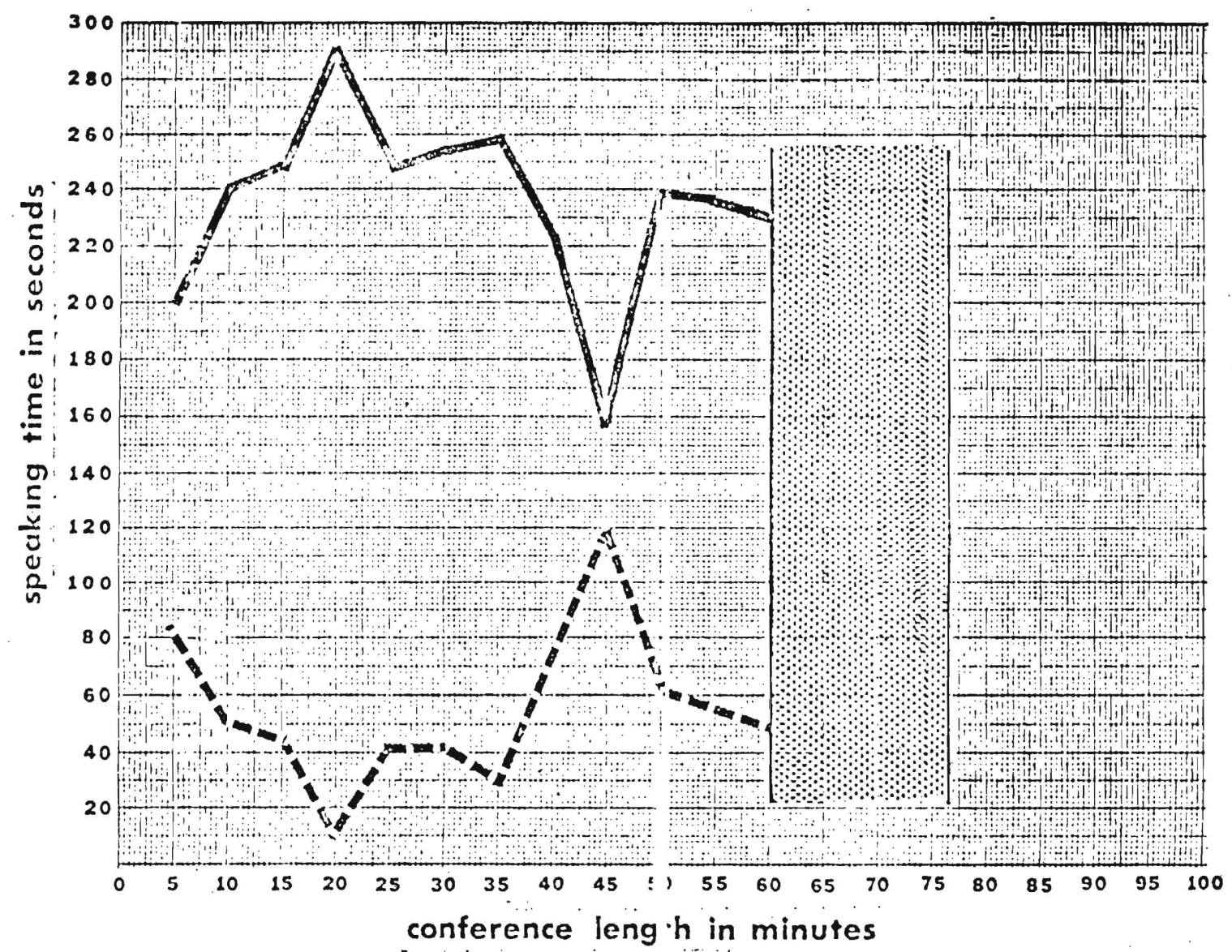

staff speaking time parent sp aking tıme $-m=-$ untaped

segments 
Figure 10. Verbal particlpation, Tape \#10

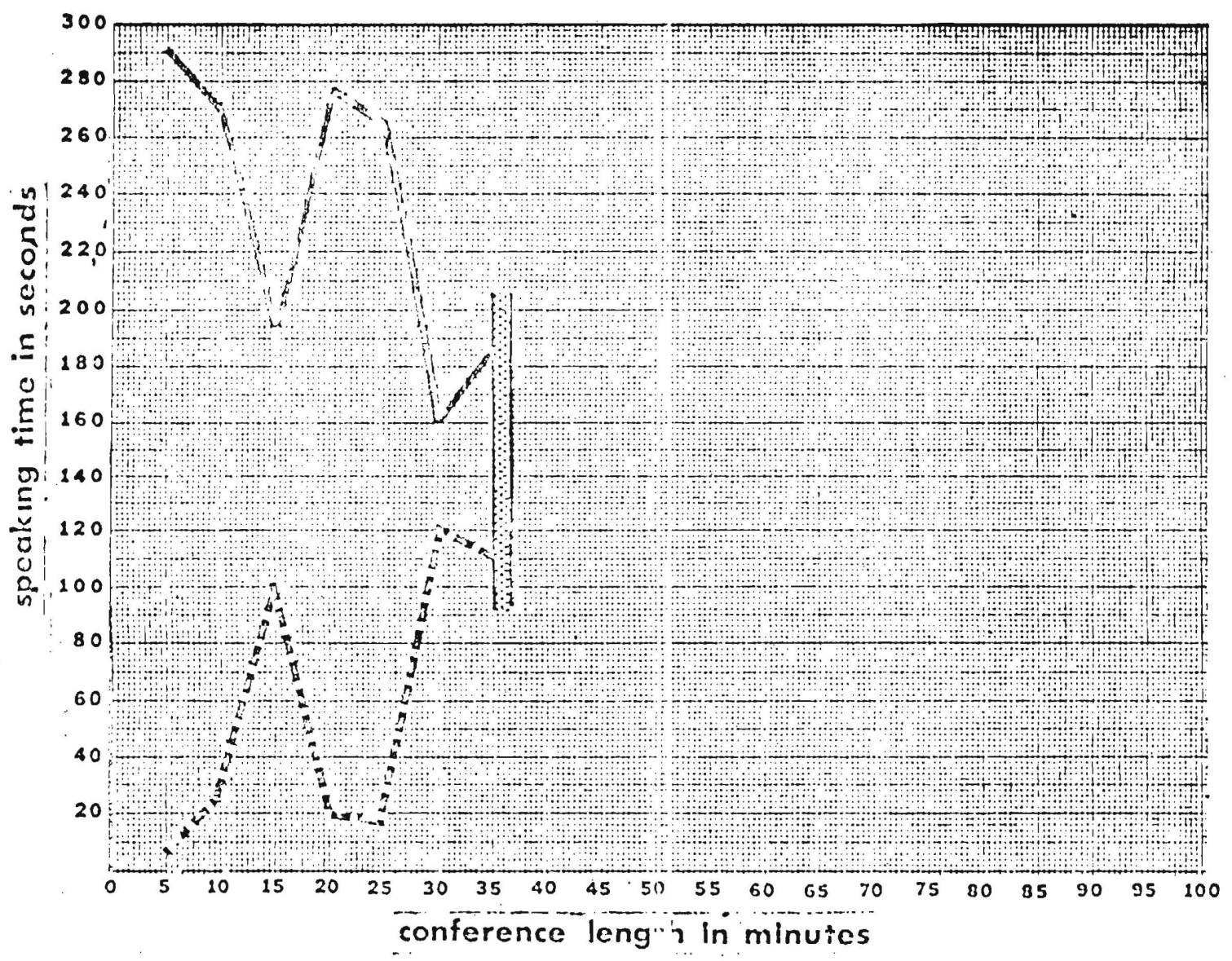

\section{staff speaking time mother speijking time-me untaped}


Figure 11. Verbal participation, Tape \#1.

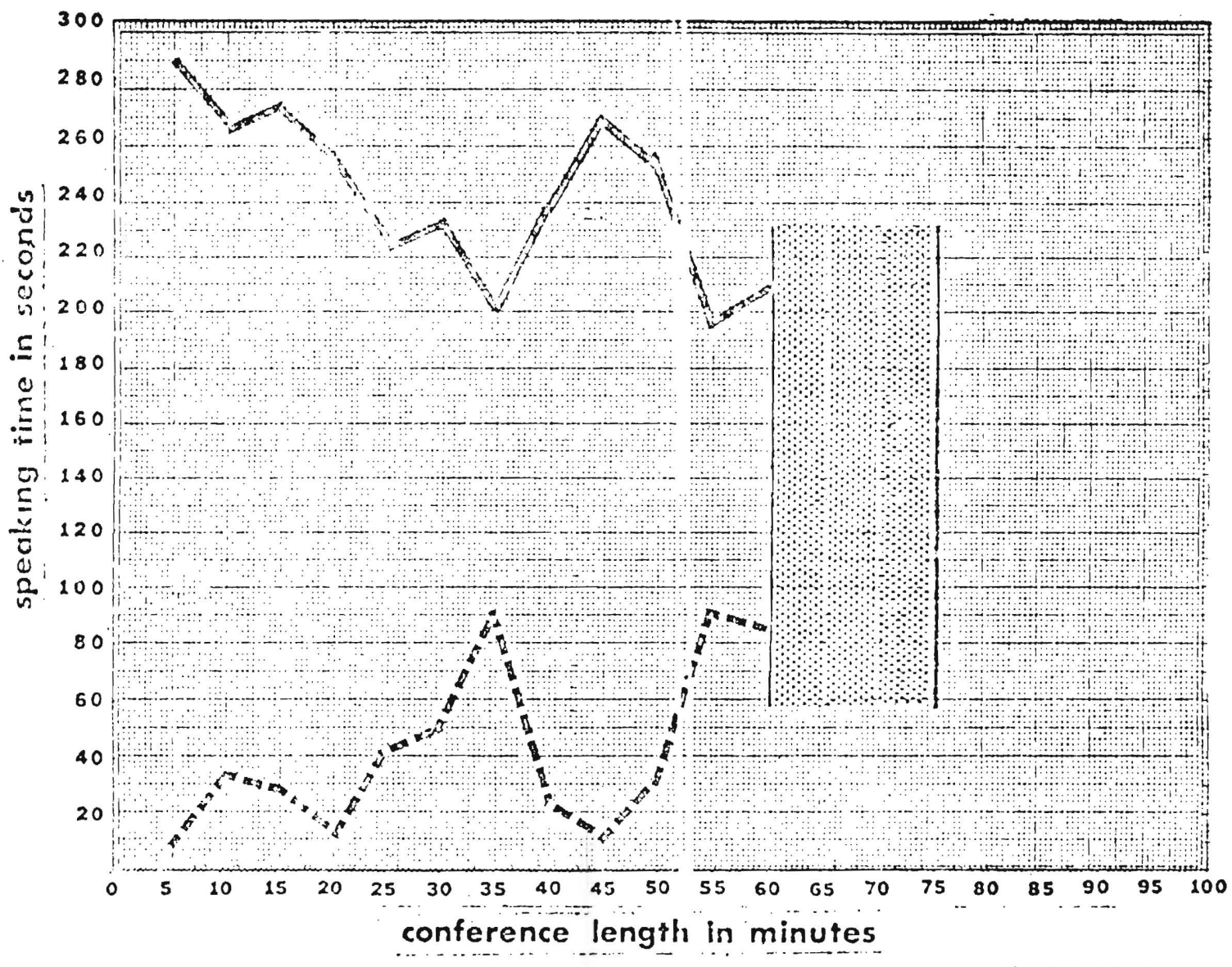

staff speaking lime parent specking time- $=$ untaped segments 
CHAPTER IV

PARENTS' SATISFACTION WITH THE CONFERENCES

Concern with parent (consumer) satisfaction is evident in the literature on counseling parents of mentally retarded or handicapped children. Such traits as honesty, warmth, and empathy are frequently cited as being very important to parents. What is most agreed upon and most often discussed is the manner in which the parents are to be treated and how the information is to be given to them. Kanner (1953, p. 375) states:

I have never encountered a parent who respected me less because, in answer to the question about the cause of his or her child's retardation, I made no secret of my inability to supply a definite answer . . . What most of them hope to hear is indeed not so much a plece of et1ological wisdom in words of Greek or Latin origin as an authoritative and sympathetic endorsement of themselves, of their human and parental competence, of their right not to blame themselves for what has happened.

Koch, in a study of parental attitudes toward the medical care of their retarded children, (1954, p. 583) concluded that, "All parents felt that the way they were told was just as important as what they were told."

The Questionnaire In this study, when the mothers were contacted, the first question asked them was "Rate your satisfaction with the parent conference by giving a number on a scale from 0 (lowest satisfaction) to 10 (highest satisfaction)." Table VIII shows the eleven responses ranked from highest to lowest satisfaction. 
In order to determine if there was any relationship between the parents' verbal participation in the conference and their satisfaction with the conference, a Spearman's Rank Order correlation was used. The correlation between parent speaking time and parent satisfaction was $r=.1818(p>.05)$. Accordingly, no relationship is apparent.

The second and third questions presented to the parents asked them to list their likes and dislikes of the parent conferences. Their responses are shown in Table IX. It can be noticed that most of the "likes" refer to process factors, such as how well the parents were treated, whereas most of the "dislikes" refer to content factors, such as not having their questions answered.

Table $X$ classifies these responses into the categories of content, process, or a mixture of the two. Using the data from Table X, a statistical analysis of the relationship between parent satisfaction and process and content was performed using Fisher's Exact. Table XI shows how the data was classifled. First, the parent's numerical ratings were divided into "high" and "low" with a score of 8 or above falling into the high category and a score of 7 or less falling into the Iow category.

To facilitate the assembly of the "likes," mixed responses with high ratings were classified as "process." The response "none" is classified as "content" when paired with a low rating. In compiling the "dislikes," the "none" responses are considered positive when paired with high scores and are classified as "process." 
TABLE VIII

PARENT SATISFACTION

TAPE \#

SATISFACTION*

PARENT

SPEAKING TIME (\%)

\begin{tabular}{lll}
\hline \hline 5 & 10 & $43 \%$ \\
1 & 10 & $34 \%$ \\
11 & 10 & $15 \%$ \\
8 & 9 & $46 \%$ \\
9 & 8 & $18 \%$ \\
6 & 7 & $42 \%$ \\
4 & 6 & $35 \%$ \\
3 & 5 & $44 \%$ \\
2 & 5 & $27 \%$ \\
10 & 4 & $20 \%$ \\
7 & 5 & \\
\hline $10=$ low satisfaction satisfaction & \\
\hline
\end{tabular}


WHAT PARENTS LIKED AND DISLIKED ABOUT THE CONFERENCAS

TAPE

\begin{tabular}{|c|c|c|c|}
\hline 5 & 10 & $\begin{array}{l}\text { Things were brought out in the open and my child } \\
\text { and I were able to discuss them. I learned a } \\
\text { lot about her school progress. We are still } \\
\text { getting results from the conferences. }\end{array}$ & None \\
\hline 1 & 10 & $\begin{array}{l}\text { It helped enlighten us. It gave us a chance } \\
\text { to ask questions. }\end{array}$ & None \\
\hline 11 & 10 & $\begin{array}{l}\text { Communication was good. We could understand } \\
\text { the non-professional talk. Everyone listened } \\
\text { to our comments and questions. }\end{array}$ & None \\
\hline 8 & 9 & $\begin{array}{l}\text { I was Iistened to by professionals. It was well } \\
\text { done. They did not pooh-pooh my concerns. They } \\
\text { took time to listen. }\end{array}$ & None \\
\hline 9 & 8 & $\begin{array}{l}\text { Straightforwardness. They didn't hedge on their } \\
\text { answers. }\end{array}$ & $\begin{array}{l}\text { Hesitant to speak } \\
\text { up in large group }\end{array}$ \\
\hline 6 & 7 & $\begin{array}{l}\text { You were } 1 \text { istening to us. Helpful, objective } \\
\text { perspectives were shared with us. }\end{array}$ & $\begin{array}{l}\text { Only } 45 \% \text { of the } \\
\text { answers related to } \\
\text { what we had in our } \\
\text { minds. We expected } \\
\text { more and were not } \\
\text { greated enlightened. }\end{array}$ \\
\hline
\end{tabular}



TAPE \#
RATING

\begin{tabular}{|c|c|c|c|}
\hline 4 & 6 & $\begin{array}{l}\text { They seemed to evaluate the problem } \\
\circ . \mathrm{k} \text {. . They pinpointed what I was } \\
\text { interested in and picked up on the } \\
\text { problems I had seen. }\end{array}$ & $\begin{array}{l}\text { Did not get any satisfactory } \\
\text { solutions to the problem. } \\
\text { Did not get the answers I } \\
\text { was looking for. }\end{array}$ \\
\hline 3 & 5 & People were nice and considerate. & $\begin{array}{l}\text { Did not get any answers. } \\
\text { What to expect in the future } \\
\text { not answered. Pediatrician } \\
\text { should have stayed for } \\
\text { entire conference. We } \\
\text { didn't find anything speci- } \\
\text { fic. }\end{array}$ \\
\hline 2 & 5 & Nothing & $\begin{array}{l}\text { Not enough found out about } \\
\text { our child. }\end{array}$ \\
\hline 10 & 4 & $\begin{array}{l}\text { Some good would come of it for self } \\
\text { and others (referring to research). }\end{array}$ & $\begin{array}{l}\text { Did not solve anything; just } \\
\text { confirmed what I had in my } \\
\text { mind. Too many staff. I } \\
\text { was strained and they could } \\
\text { have done more to make me } \\
\text { at ease. One trainee did } \\
\text { not talk. }\end{array}$ \\
\hline $7^{*}$ & 0 & Nothing & $\begin{array}{l}\text { It was confusing because } \\
\text { different people said } \\
\text { different things. The new } \\
\text { diagnosis made it hard. }\end{array}$ \\
\hline
\end{tabular}

* patient-respondent 
The mixed response, paired with a low rating, is classified as "content." Thus, positive and negative responses have been clustered. As shown on Table XI, the results of the Fisher's exact $(p=.045, p=.002)$ indicate that parents who rate the conference high cite process factors and parents who rate the conference low cite content factors. Following the results of the remainder of the questionnaire, there is a discussion of the implications of the above findings.

Question 4, "Did anything about the parent conference make it different from other parent conferences you have particlpated in?," elicited the responses found in Table XII. Aside from not having had a comparable experience, the mothers made reference only to process factors, including the one negative experience related by $\# 0$.

The fifth and final question, "Does your husband feel any differently about the conference?," was applicable in seven instances where fathers had participated (see Table XIII). All the mother-respondants said they thought their husbands felt like they did.

Discussion Having established a relationship between parent satisfaction and process in the parent conference, and parent dissatisfaction and content in the parent conference, perhaps it would be useful to speculate as to what factors might account for the differences in experiences reported by parents participating in the conferences. The literature, in one instance, suggests that it is the parents ${ }^{\circ}$ perceptions of their child as they enter the parent conference that determines their satisfaction. Sheimo, in his review of the literature 
TABLE $X$

CLASSIFICATION OF RESPONSES

\begin{tabular}{cll} 
RATING & LIKES & DISLIKES \\
\hline 10 & Mixed & None \\
10 & Process & None \\
10 & Process & None \\
9 & Process & None \\
8 & Process & Process \\
7 & Mixed & Content \\
6 & Content & Content \\
5 & Process & Content \\
5 & None & Content \\
4 & Content & Mixed \\
0 & None & Content
\end{tabular}


TABLE XI

FISHER'S EXACT

\begin{tabular}{|c|c|c|c|}
\hline & & $\underline{\text { LIKES }}$ & \\
\hline & process & content & total \\
\hline high & 5 & 0 & 5 \\
\hline low & 2 & 4 & 6 \\
\hline total & 7 & 4 & 11 \\
\hline
\end{tabular}

DISLIKAS

\begin{tabular}{l|c|c|c|}
\multicolumn{1}{c}{ high } & process & content & total \\
\cline { 2 - 4 } & 5 & 0 & 5 \\
\cline { 2 - 4 } low & 0 & 6 & 6 \\
\hline total & 5 & 6 & 11 \\
\hline
\end{tabular}

$$
p=0.002
$$


TABLE XII

PARENT RESPONSES TO QUESTION \#4

(Did anything about this parent conference make it different from other parent conferences you have participated in?)

TAPE \#

RESPONSE

1 It was the first time we've done this together and it's new to my husband.

Didn't have any other conference so can't tel.l.

3 People were nicer here; they seemed caring. Before, it was "go home and be on your own." They wanted to find out where to go from here.

4 No prior experience in a multi-disciplinary conference. I couldn't grasp the medical terminology.

It was different because the parent's personal feelings were considered as much as the child's.

6 No prior experience.

$7 \quad$ No way to compare.

8 Nothing different. I've been in others and they get easier.

(No applicable answer.)

10 There wasn't a discussion like in other conferences. I didn't contribute because of the strain.

11 Everyone gave us the feeling they were concerned about our son, our family, and us as individuals. We weren't a name and a number. 
TABIE XIII

PARENTS RESPONSES TO QUESTION \#5

(Does your husband feel any differently about the conference?)

TAPE \#

RESPONSE

$\begin{array}{ll}1 & \text { He feels the same as I do. } \\ 2 & \text { We feel the same. (written response) } \\ 3 & \text { He feels pretty much the same; perhaps more } \\ \text { negative } & \text { He didn't understand too much of anything } \\ 4 & \text { and didn't benefit at all. He'd rate it } \\ \text { the same. } & \text { N/A* } \\ 5 & \text { He feels pretty much the same. } \\ 6 & \text { N/A* } \\ 7 & \text { N/A* } \\ 9 & \text { He feels the same as I do. } \\ 11 & \text { N/A* }\end{array}$

*Tapes \#5, \#8 and \#10: these mothers were not accompanied by their husbands. Tape \#7 included the patient and her advocate. 
on parental attitudes, (1951, p. 44) states;

It also became progressively more evident that the doctor's mere presentation of clinical diagnosis and recommendation was neither sufficient nor perhaps really what the parents were seeking. Advice and suggestions seemed to be of no avall and unconsciously impossible for the parents to accept and find useful. In an attempt to help these parents, it is necessary for the doctor to become more sympathetically aware of the conflicting attitudes of the parents toward such a child.

The attitude referred to here is acceptance. Perhaps it is the degree of acceptance of the child's condition which either permits or hinders parents from making use of the parent conference. It may be that those parents who said they liked the conference had reached a psychologically crucial point when it is time to say, in effect, "O.K., our child is handicapped. Now what are we going to do about it?" Stone, (1947, p. 372) who studied parental awareness of retardation in their children prior to and after diagnostic services in a child guidance clinic, concluded "that learning does not take place unless the learner is at least partially ready for 1t."

Parental receptivity might be taken into account by staff who are assessing their effectiveness in parent conferences. If, for instance, staff judged that they had responded to parents' questions relatively equally in a number of conferences yet some parents felt this was true and others thought their questions were not answered, staff might begin to look at the parents' acceptance of their child as an influence. It is interesting to note that parents in the study, who rated their conference satisfaction high, did not mention that their questions had been answered. Perhaps the apparent agenda, the diagnosis and recommendations, is not what is most important either to the 
satisfied parent or the dissatisfled parent. There may be a less visible but more pressing issue involved. For the satisfied parent that issue, the acceptance of the handicapped child, may be at least partially resolved. For the dissatisfied parent, who felt that his questions had not been answered, that issue, beyond the parent's awareness, prevented him from benefitting from the conference. While parents' attitudes about their children may change in the course of an evaluation, the parent conference can only take into account parental acceptance and not impact on it heavily. 


\section{CHAPTER V}

\section{CONCLUSIONS}

Verbal participation in eleven parent conferences has been described in detail. The parents, and in one instance, the patient herself, have rated their satisfaction numerically as well as Iisted their likes and dislikes about the parent conferences.

The author found wide variety in the verbal participation of staff and parents. Parent satisfaction was not found to be related to the amount of verbal participation but was found to be related to process and content factors.

The study, being exploratory in nature, does provide a beginning step for further inquiry into other factors influencing parent satisfaction with the conference. If a reliable measure could be found, it would be useful to measure parental adjustment to the handicapped child and examine any relationship between that adjustment and satisfaction with the parent conference. Another area for study would be to measure staff's ability to percelve how satisfied parents are with the conference as it is in progress. 
Begab, M.J., "Factors in Counseling Parents of Retarded Children," American Journal of Mental Deficiency, 1956, Vol. 60, pp. 515-524.

Boyd, D., "The Three Stages in the Growth of a Parent of a Mentally Retarded Child," American Journal of Mental Deficiency, 1951, Vol. 55, pp. 608-611.

Caldwell, B. et al., "Factors Associated with Parental Reaction to a Clinic For Retarded Children," American Journal of Mental Deficlency, 1961, Vol. 65, pp. 590-594.

Cohen, P., "The Impact of the Handicapped Child on the Family," Social Casework, 1962, Vol. 43, pp. 137-142.

Daggett, B. et al., "Counseling Problems That Accompany the Diagnosis of Mental Retardation," Master's Practicum. Portland. Portland State University, 1973.

Drayer, C. and Schlesinger, E., "The Informing Interview," American Journal of Mental Deflclency, 1969, Vol. 65, pp. 363-368.

Farber, B., "Effects of a Severely Mentally Retarded Child on Family Integration," Monographs of the Soclety for Research in Child Development, 1959, Vol. 24, pp. 5-112.

Gorham, K. et al., "Effect on Parents." In N. Hobbs (Ed.) Issues in the Classification of Children, Vol. II. San Francisco: Jossey-Bass, 1975, pp. 285-288.

Goodman, L., "Continuing Treatment of Parents with Congenitally Defective Infants," Social Work. 1964, Vol. 9, pp. 92-97.

Graliker, B.V. et al., "Attitude Study of Parents with Mentally Retarded Children," Pediatrics, 1959, Vol. 24, pp. 819-821.

Grebler, A.M., "Parental Attitudes Toward Mentally Retarded Children," American Journal of Mental Deficiency, 1952, Vol. 56, pp. 475-483.

Haskell, E.N. et al., "The First Three Years of a Clinic for Mentally Retarded Preschool Children," Journal of the Maine Medical Assoclation, 1961, Vol. 52, pp. 47-53. 
Hastings, D., "Some Psychiatric Froblems of Mental Deficiency," American Journal of Mental Deficiency, 1948, Vol. 52, pp. 260-262.

Hersh, A., "Casework with Parents of Retarded Children," Soclal Work, 1961, Vol. 6, pp. 61-66.

Jensen, R., "The Clinical Management of the Mentally Retarded Child and the Parents," American Journal of Pediatrics, 1950, Vol. 106, pp. 830-833.

Kanner, I., "Parent's Feelings About Retarded Children," American Journal of Mental Deficiency, 1953, Vol. 57, pp. 375-383.

- "Parent Counseling," In J. Rothstein (Ed.) Mental Retardation. New York: Holt, 1963, pp. 32-43.

Llewellyn, E., "Counseling with Parents of Handicapped Children," Journal of the Medical Association of Alabama, 1962, Vol. 31, pp. 329-332.

Mc Intire, M.S. and Klekhaeker, T., "Parental Reaction to a Clinic for the Evaluation of the Mentally Retarded," Nebraska Medical Journal, 1963, Vol. 48, pp. 69-73.

Mahoney, S., "Observations Concerning Counseling with Parents of Mentally Retarded Children," American Journal of Mental Deficiency 1958, Vol. 63, pp. $81-86$.

Murray, M., "Needs of Parents of Mentally Retarded Children," American Journal of Mental Deficiency, 1959, Vol. 63, pp. 1078-1088.

Rainbault, G. et al., "Aspects of Communication Between Patients and Doctors: An Analysis of the Discourse in Medical Interviews," Pediatrics, 1975, Vol. 55, pp. $401-405$.

Rheingold, H., "Interpreting Mental Retardation to Parents," Journal of the Consulting Psychologist, 1945, Vol. 9, pp. 142-148.

Rogers, R. and Rasof, B., "A Teaching Drill in Child Psychiatry," American Journal of Psychiatry, 1975, Vol. 132, pp. 158-163.

Roos, P., "Psychological Counseling with Parents of Retarded Children," Mental Retardation, 1963, Vol. 1, pp. 345-350.

Ryckman, D.B. and Henderson, R.A., "The Meaning of a Retarded Child for His Parents: A Focus for Counselors," Mental Retardation, 1965, Vol. 3, pp. 4-7.

Sampson, A.H., "Developing and Maintaining Good Relations with Parents of Mentally Deficient Children," American Journal of Mental

Deficiency, 1947 , Vol. 52, pp. 187-194. 
Schumacher, H., "Contribution of the Child Guidance Clinic to the Problem of Mental Deficiency," American Journal of Mental Deficiency, 1945, Vol. 50, pp. 277-283.

Scheimo, S.L., "Problems in Helping Parents of Mentally Defective and Handicapped Children," Amerlcan Journal of Mental Deficiency, 1951, Vol. 56, pp. 42-47.

Stone, M, "Parental Attitudes to Retardation," American Journal of Mental Deficiency, 1948, Vol. 53, pp. 363-372.

Thurston, J., "Attitudes and Emotional Reactions of Parents of Inst1tutionalized Cerebral Palsied, Retarded Patients," American Journal of Mental Deficiency, 1960, Vol. 7, pp. 227-235.

Warren, S., "The Distressed Parent of the Disabled Child," In W. Klopfer and M. Reed (Eds.) Problems in Psychotherapy: An Eclectic Approach. New York: Halstead, 1974, pp. 129-134.

Wolfensberger, W., "Counseling Parents of the Retarded," In A.A. Baumeister (Ed.) Mental Retardation: Appraisal, Education, and Rehabilitation. Chicago: Aldine, 1967, pp. 329-400.

Zwerling, I., "Initial Counseling of Parents with Mentally Retarded Children," Journal of Pediatrics, 1954, Vol. 44, pp. 469-479. 
QUESTIONNAIRE

1. Rate your satisfaction with the parent conference by giving a number on a scale from 0 (lowest satisfaction) to 10 (highest satisfaction).

2. What did you like about the parent conference?

3. What did you not like about the parent conference?

4. Did anything about this parent conference make it different from other parent conferences you have participated in?

5. Does your husband feel differently about the conference? 